Northwestern University School of Law Northwestern University School of Law Scholarly Commons

Faculty Working Papers

1967

\title{
Legal Aspects of the French Nuclear Tests
}

Anthony D'Amato

Northwestern University School of Law, a-damato@law.northwestern.edu

\section{Repository Citation}

D'Amato, Anthony, "Legal Aspects of the French Nuclear Tests" (1967). Faculty Working Papers. Paper 123.

http://scholarlycommons.law.northwestern.edu/facultyworkingpapers/123

This Article is brought to you for free and open access by Northwestern University School of Law Scholarly Commons. It has been accepted for inclusion in Faculty Working Papers by an authorized administrator of Northwestern University School of Law Scholarly Commons. 


\title{
Legal Aspects of the French Nuclear Tests, by Anthony D'Amato,* 61 AJIL 66-77(1967)
}

\begin{abstract}
Even at the level of scholarly or diplomatic argumentation it is important to inquire into the competing interests and legal factors involved in the atmospheric tests. This is true not only because differing political expectations or even measures might depend on the consensus as to the legality or illegality of the French tests, but also because the precedential value of the tests will be of greater or less force depending upon whether there is agreement at the time of the tests that France was or was not acting within her international legal rights.
\end{abstract}

Tags: French nuclear tests, Nuclear tests, Nuclear Test Ban Treaty of 1963

[pg66]** The question of the legality of France's nuclear test series, commenced on July 2, 1966, in French Polynesia, will probably stop short of any definitive third-party determination and be subjected only to general community appraisal. Yet even at the level of scholarly or diplomatic argumentation it is important to inquire into the competing interests and legal factors involved in the atmospheric tests. This is true not only because differing political expectations or even measures might depend on the consensus as to the legality or illegality of the French tests, but also because the precedential value of the tests will be of greater or less force depending upon whether there is agreement at the time of the tests that France was or was not acting within her international legal rights.

French Polynesia consists of 130 small islands, of which Tahiti is the largest and most famous, located approximately 2,400 miles south of Hawaii, 4,200 miles east of Australia, and 5,000 miles west of Chile. The islands comprise a land area of 1,544 square miles and support an intra-migrant population of approximately 90,000 "Polynesians," a unified racial stock descendant of the Maori. The main French test base is located on Mururoa Atoll in the Tuamotu Archipelago, one of five major archipelagos. Other facilities include a jet airport on Hao Island and two subsidiary airstrips on the Anaa Atoll. Housing and facilities for French personnel, currently numbering over 13,500, are located primarily on Tahiti in the Society Islands Archipelago 750 miles northwest of Mururoa. In order to make room for the ever increasing number of French scientists, technicians, and military personnel, a company working with French capital has been buying, under threat of expropriation, many of the largest and best residential properties in Tahiti. In the twelve months prior to July, 1966, rent on Tahiti increased 18 percent and the general price index rose 15 percent.

In the 1840's, France had established protectorates over most of the small autonomous kingdoms on the various islands in Polynesia or "Oceania," and by mid-1880 France was treating the entire cluster of islands as a colony. The actual administration of the area as a single entity dates from 1903. After the second world war French Polynesia was denoted a "French Overseas Territory" under the French Union of 1946 and has retained that status under the new French Community of the Fifth Republic as a result of the referendum of September 28, 1958.

Several nations, including Australia, New Zealand, Chile and Peru have lodged diplomatic protests with France concerning the proposed nuclear [pg67] tests. In addition, Chile has suspended commercial relations with France. Several other countries, including the United 
States, have at times refused to transport French personnel to the islands, citing the Nuclear Test Ban Treaty of 1963 in support of their refusal, but France has managed, using different national airlines, to staff the test sites to its own satisfaction. The initial explosion on July 2, 1966, of a nuclear device believed to have an explosive force of less than one megaton of TNT elicited official statements of regret from the United States and British Governments (the Soviet Government did not comment upon the test, which occurred just after President de Gaulle's visit to Moscow). However, the initial French tests have been confined to low-yield atomic weapons; hydrogen bombs are not expected to be exploded until the latter half of 1967 at the earliest. No prediction can be made as to the intensity of international reaction to the hydrogen bomb tests on the basis of diplomatic reactions in 1966 to the first few atmospheric low-yield tests.

The lack of pervasive international condemnation of the initial tests in the French series was not paralleled by local Polynesian reactions. Seven months before the first explosion the New York Times reported that "the native population is almost unanimously opposed" to the test program. FN1 Tahiti's Deputy to the French National Assembly is on record as having voiced strenuous opposition to the tests on the grounds of radioactive fallout in the atmosphere and nuclear pollution of the sea effected by the migration of fish and the drift of plankton. FN2 The President of the French Polynesian Territorial Assembly has publicly declared his opposition to the proposed tests, FN3 as have other leading citizens-including Frenchmen long resident in Polynesia-despite risk of reprisal from the French authorities. FN4

The logical starting point for legal analysis of this situation is Professor McDougal's essay in support of the legality of the United States' nuclear test program of 1954 on strategic Trust Territories in the Pacific Ocean. FN5 By arguing that the nuclear tests constituted a "reasonable" and "minimal" incursion upon the traditional rights and claims of navigation and fishing associated with the "free" regime of the high seas, Professor McDougal left himself open for subsequent criticism that any nation could, in an appropriate context, justify as "reasonable" a use of the high seas for nuclear testing. FN6 Yet a fair reading of his essay demonstrates that Professor McDougal clearly had in mind two separate "weights" or sets of interests that required balancing upon the scales of reasonableness: the reasonableness of the infringement on traditional [pg68] claims to the use of the high seas and the importance of the tests to the "free world" acting through its agent, the United States. Unfortunately Professor McDougal did not elaborate at length on this latter element, taking it perhaps rightly for granted that few readers would disagree that the United States was acting, in the Cold War setting of the 1950's, on behalf of inclusive interest. But it is nevertheless clear that any claim of temporary expropriation of a portion of the earth's oceanic surface and atmosphere for nuclear tests must be assessed in part according to the importance of the test program to the testing nation and to other nations.

An attempt to make an objective evaluation of the importance of the French tests to France's legitimate security interests and the security interests of other nations immediately plunges us into a maelstrom of factors of difficult or ambiguous reference in their bearing upon the interests at stake. Nevertheless, the attempt should be made if international law is to be grounded in political reality. In the first place, it should be noted that nearly all the nations of the world except Communist China and France have indicated by their signing or ratification of 
the Nuclear Test Ban Treaty of 1963 that they have no present need for a national nuclear force.FN7 This is reinforced by the General Assembly resolution of the Seventeenth Session condemning all nuclear weapons tests, which was adopted 75 to 0 . FN8 It would therefore seem, at least initially, that France's claim for its own force de frappe would have to be evaluated fairly strictly in the light of the overwhelming international consensus that national nuclear deterrents are not at present necessary. Or to put the matter differently in order to contrast the present French claim with that of the United States in 1954 as asserted by Professor McDougal, it appears that the overwhelming majority of nations have acquiesced in the argument that the United States' tests were necessary and reasonable in order to provide a deterrent for the United States and its allies (the "free world" of Professor McDougal) against the Soviet Union and its allies, but that once such a bipolar balance of nuclear power was effected, no further independent national elements were required for international stability.

Of course France may argue that most nations have not properly evaluated their own security requirements and that they joined in the Test Ban Treaty because of political pressures. But what, then, is the case that France submits for independent national nuclear deterrents? Three general arguments may be discerned. The most recent is that France cannot afford to be tied to NATO (or "free world") defenses, since a war between the United States and the Soviet Union (such as the one that might have started during the Cuban missile crisis of 1962) might involve France as a NATO ally, even if France were not consulted in advance about the war. Therefore France must withdraw from the NATO nuclear [pg67] defense system and establish a nuclear deterrent of her own.FN9 This argument appears rooted in emotionalism and not logic: if France loses its component of the NATO nuclear defense system, it does not logically follow that it must replace this "loss" with a nuclear deterrent of its own. It could simply withdraw from the "nuclear club." Thus, France usually tends to couple the NATO argument with the more long-standing one that an independent nuclear deterrent is necessary for the restoration of French prestige in the eyes of the world, if not for French "grandeur." But this argument, as well, need not be persuasive to outside observers (even though it might be subjectively, and unilaterally, compelling to France itself). A political realist, for example, might question whether Great Britain has derived enormous diplomatic benefits from her national deterrent over the last decade, or whether Communist China has increased its world-wide prestige in the last three years since exploding its first nuclear device. Apart from this line of inquiry, as to which differing opinions might well be forthcoming, the more general objection from an international standpoint to the French argument for "grandeur" is that an enlarged nuclear club composed, in the next few years, of many nations who follow France's example, will bring grandeur to none and perhaps insecurity to all. In short, the French grandeur argument, carried to the limit of its logic, is completely self-defeating and thus articulates no reasonable ground for international acceptance of the necessity for the French nuclear tests.

But there is a third French argument, rooted in the premise of the lack of credibility and reliability of the United States' nuclear-deterrent umbrella, that is not so easily refuted. As articulated primarily by General Pierre M. Gallois, FN10 the argument is that a nation as small as France would not be able to present the threat of complete nuclear devastation against a country such as the Soviet Union, but at least could inflict damage equivalent in amount to that 
which the Soviet Union could inflict in an attack upon the territory of France. For instance, France would be able to retaliate against a Soviet attack by employing its force de frappe to destroy, say, four major Russian cities. This limited deterrence potential would be enough, argues Gallois, to induce Russia to avoid any attack upon France either as part of a strategy of general nuclear warfare or in a non-nuclear invasion of France. The international extension of this argument, presumably, is that, if every country adopts its own limited deterrent, then it would never be advantageous for any of the super-Powers to attack the smaller nuclear-armed nations.

Looking first at the latter (the multilateral) implication of the French position, it is quite evident, by virtue of the fact that other nations have not been convinced by the Gallois argument, that they see great dangers in a world characterized by complete national nuclear proliferation. The dangers of accidental, catalytic, unauthorized or miscalculated war appear [pg70] much greater if the nuclear deterrent is changed from a bipolar to a multipolar system. But even apart from this, there is a certain grave lack of reality in the psychological underpinnings of the Gallois position that other nations seem to have noticed. Positing the outbreak of a general thermonuclear war, would a super-Power in fact avoid a nuclear Power such as France or would the super-Power make sure to deal with such a Power initially in order to avoid the possibility that an unscathed France might emerge as world dictator? Carrying the question further, would the French threat to commit national suicide in exchange for obliterating four cities be credible? If it were at all credible, would not the super-Power make sure initially to destroy this French capability? Moreover, in the event of a non-nuclear military attack against France, would there be any credibility in a French threat to destroy four Russian cities if the attack is not stopped in twenty-four hours? Would not even the possibility of such a threat induce a Soviet pre-emptive nuclear attack against the force de frappe? Indeed, this latter possibility suggests the weird scenario that in the event of a heightening of tension between France and Russia where military attack is contemplated, the most rational act for France would be publicly to dismantle and destroy its force de frappe so as not to invite a suicidal nuclear exchange. Of course, nations do not invariably behave with utmost rationality in crises. But this very fact should alert the international community all the more to the apparent lack of reasonableness in the French arguments used to justify her atmospheric tests in Polynesia.FN11

To some it may appear unusual to investigate, however briefly, the bases of a unilateral policy decision by France in a paper concerned with international law. Nevertheless, the two are related, not on the level of the wisdom of France's actions, when France alone is considered, but on the level of their reasonableness as a claim for the use of resources which may in part be protected by international law for the use of others. The quality of France's actions in terms of the genuine common interests of states bears upon the reasonableness of the deprivations they impose upon others. Our brief examination of the French position, thus, may be seen to have resulted in the following conclusion: that compared to the United States' reasons for its nuclear test series in the Pacific in 1954 (as the agent for one side in a global bipolar nuclear deterrence system), the French arguments for the necessity of a French national nuclear [pg71] deterrent are significantly less convincing, and hence objectively less reasonable insofar as nations other than France are concerned. 
This relative difference in the threshold of reasonableness would indicate that France would, at the very least, have to present a strong case that the infringement caused by the atmospheric tests on the legitimate interests of other nations are indeed minimal and reasonable. On the other hand, if it were to appear that the French tests would clash more seriously with stronger competing claims and interests than did the United States' tests, then France would have a much less persuasive claim of legality to make. In other words, France would have a lower, perhaps decisively lower, "coefficient of legality" on the scales of reasonableness than the United States on the basis of the weights on both ends of the scale. It is therefore necessary at this point briefly to examine the competing interests that are involved.

The first category concerns the interests of the Polynesian people. The fact of their opposition to the French nuclear tests has already been mentioned; the question is whether they have interests cognizable under international law. Such interests, if they exist, could not be at the level of an independent member of the international community, since Polynesia is not a state. Yet if Polynesia is a potential state, then its incipient interests may carry some degree of persuasiveness in the international community. Even apart from this, the concept of partial sovereignty, FN12 viewed in a colonial situation affecting the rights of underdeveloped peoples, adds international legal force to the claims of the natives of Polynesia. Several facts buttress these positions of potential nationhood or partial sovereignty. First, the increasing tendency of peoples to break from the mother country and the rising international consensus against colonialismFN13 demonstrate that, despite the outcome of the referendum of 1958, Polynesia may someday in the not-too-distant future become a state. Second, Polynesia has the geographic characteristics of a state and has long been regarded by the rest of the world as an integral area. Its territory is 50\% larger than that of the state of Luxembourg and its population is 500\% more numerous than Liechtenstein's. The people have a relatively homogenous racial and cultural background. Third, the islanders regard themselves as a nation, and have repeatedly demanded more of the rights of nationhood and self-determination through the large native political party, the Democratic Rally of Tahitian Populations. Their opposition to the French tests is typically couched in terms of self-determination. Fourth, France may be said to have recognized the possibility of independence in 1958, since the referendum gave to all of her colonies the option of independence. Fifth, an analysis of the results of the 1958 referendum show that French Polynesia came closer to opting for independence than all the other French colonies exclusive of Guinea (which under Sékou Touré achieved independence): out of a total population of over 60,000 in 1958, [pg72] only 30,950 were registered to vote, and only 25,148 votes were actually counted by the French officials. Of the latter, 16,196 voted to accept the new Constitution and 8,952 to reject it in favor of independence.FN14 On a comparative basis, (a) a considerably larger percentage of counted votes was cast against the Constitution (approximately 36\%) as compared with the percentage results in other French territories (6\%) or the French Community exclusive of Guinea (14\%), and (b) a considerably smaller percentage of votes was cast for the Constitution out of the total population than in other territories. FN15 Moreover, the circumstances of the election give some ground for caution. The only strong leader of the Polynesians at the time-Pouvanna Oopa, head of the D.R.T.P.—was arrested by the French two weeks after the referendum and two months prior to the final vote of the Territorial Assembly. 
Oopa was not formally charged with a crime (treason and sabotage) until one year after his arrest and incarceration. He was sentenced to eight years in prison, and fifteen of his followers who were arrested along with him received sentences of up to six years. Finally, if a referendum were conducted today, the results might be different because the Polynesians did not know in 1958 that France was going to use a portion of their territory for nuclear tests. This strengthens the Polynesian claim to potential nationhood, or at least to partial sovereignty, in that a rebus sic stantibus argument might be advanced as to the 1958 referendum.

A different basis for arriving at an international recognition of Polynesian interests might be found in Article 73 of the United Nations Charter. If Polynesia were a "non-self-governing territory" under this article, then France would be under a duty to "recognize . . .that the interests of the inhabitants ... . are paramount" and to "ensure ... their political, economic, social, and educational advancement, their just treatment, and their protection against abuses." Although France vigorously denies that Polynesia is a "non-self-governing territory" under Article 73, it did submit information under Article 73(e) in 1946 as to "French Establishments in Oceania." Some statistics were submitted on the Polynesian group as a whole and on the phosphate-mining island of Maketea in the Tuamoto group in particular. FN16 At that time a number of other nations also submitted reports on dependent territories, and the question then arose whether a verbal definition of "non-self-governing territories" should be attempted. The General Assembly in its first session decided not to do so, instead passing a resolution which mentioned as nonself-governing territories under Article 73 all of the territories which had been included in the reports of all the administering nations including "French Establishments in Oceania."FN17 Although France decided the next year to stop giving information about Polynesia, an argument of [pg73] estoppel can be made on the above facts. For it is arguable that the General Assembly would not have passed a resolution naming specific territories, had there not been a large number of territories with respect to which administering authorities had submitted information. A lesser number might well have induced the General Assembly to formulate a broad verbal definition in order to gather in more territories. Thus the Assembly may be said to have relied in part on the French inclusion of Oceania. Moreover, the French action of including Polynesia in 1946 would seem to reflect actual French understanding at the First Session of the General Assembly as to the intention of the framers of the Charter to include territories such as Polynesia. Certainly the terms of the resolution later adopted by the General Assembly in its Eighth Session, setting down a definition of "non-self-governing territory," would easily include a territory such as Polynesia. FN18

If the preceding arguments are accepted, we may conclude that the Polynesian people have a basis for an internationally cognizable complaint. Yet, the complaint cannot persuasively be made in the abstract; it must be grounded in the predictable damage that the French nuclear tests will do to the territory and people of Polynesia. The low-yield nuclear tests started on July 2, 1966, and continuing for several months thereafter at the rate of about two explosions per month have apparently not caused so far a significant impact on the marine life of the area nor significantly polluted the atmosphere. But the test program will increase in megatonnage; the high-yield hydrogen bomb devices will be detonated in 1967; and it may even take several years after that for the impact of the damage to the area caused by nuclear shock-waves and fallout to 
be scientifically assessed. Thus, only general and admittedly vague predictions can be attempted at the present time.

Clearly the tests will contaminate some, and perhaps much, of the fish in the surrounding waters of the test sites. Given the intra-migrant character of the population and its dependence upon fish as a staple item of the diet, some danger from this source to the population is incontestable. Moreover, radiation could indirectly upset the genetic balance of marine organisms in the area. FN19 The people themselves may be adversely affected by direct radiation. Precedent for this is afforded by the Marshall Islands tests conducted by the United States in the early 1950's. A United Nations Visiting Mission to the Marshall Islands in 1956 reported that skin contamination from these tests, despite the elaborate precautions taken by the United States authorities, was notable in the case of three island groups and extensive in the case of the Rongelap Islanders. The people had suffered from irradiation in three ways: penetrating gamma radiation from the ground, trees and houses affecting the whole body; skin contamination from fallout; and internal contamination from the ingestion of contaminated food and air. White blood cells were depressed to about [pg74] 50\% of normal and platelets to 30\% of normal four to six weeks after exposure to radiation, thus drastically increasing susceptibility to other diseases and infection. Finally, with respect to the homes of the inhabitants, the Visiting Mission concluded that displacement from homes in Bikini and Eniwetok "is likely to be permanent." FN20 Since the tests in Polynesia are to be conducted on islands that form an integral part of the territory, since many fishermen use these islands at least as temporary bases (there are few actual homes on the islands selected by France for the test sites), and because France has neither the technical experience of the United States nor the financial resources which may be devoted to safeguarding the test sites, it may well be argued that the French tests constitute at least as great, and perhaps a greater, threat to the people of Polynesia than those of the United States constituted to the Marshall Islanders. When coupled with the internationally cognizable interests of the Polynesians (compared to the "strategic trust territory" permissiveness of the United States' testsFN21), important doubts are raised whether the international community could or would accept the French claim of legality as to its nuclear testing program.

A second category of interests may be characterized by the rubric "freedom of the seas" (and of the superjacent airspace). As Professor McDougal has demonstrated this really means freedom to use the seas for reasonable purposes. Some of these purposes might include the temporary use of an exclusive area of the seas for naval maneuvers, military exercises, or perhaps nuclear testing. Any given claim for a use of the seas must be balanced against the reasonable competing claims of other nations for the use of that portion of the seas for traditional purposes. It is fortunately unnecessary here to examine the general relationship between these claims, for other writers have done so at some length. The relation between nuclear tests on the one hand and fishing and navigation rights on the other have been dealt with extensively. FN22 Also studied have been the relationships between nuclear tests and air and sea pollution, FN23 nuclear tests and evolving standards of humanitarianism, FN24 and nuclear tests and the Hague Conventions of 1899 and 1907 and the Geneva Protocol of 1925 on Poisonous Gases. FN25 While no one is in a position, in the light of present [pg75] knowledge, to make a definitive weighing of the competing interests with respect to the French nuclear tests, all reports of the 
French preparations and the manner in which the tests series has been started in 1966 indicate that the test program is to be relatively long in duration and will cover a variety of weapons (hydrogen bombs, missiles, safety devices, and so forth). It is therefore possible that considerable damage will result to fishing in the area and that navigation and airline routes will be interrupted for a long period of time. Furthermore, due to the additive effects of nuclear radioactivity, it is altogether possible that tests in the Pacific Ocean prior to the French tests might have approached the maximum tolerance levels for the bird, marine and animal life in the area. Additional deposits of radioactivity from new tests might exceed these levels and thus constitute a qualitative difference in the danger threshold. The notorious disagreement among scientists as to the quantification of the danger of radioactivity to living organisms does not invalidate this reasoning, for it is clear that every living organism has its own maximum tolerance level and that an increase in the general amount of radioactivity in an area carries with it the statistical likelihood of surpassing this tolerance level for at least some of the organisms in the region at a certain distance from the test sites. The cumulative effect of nuclear testing can only serve to increase the danger to organisms in the area. Any new dose of radioactivity might be the last straw for large numbers of organisms. Moreover, the extinction of any particular species of life in the area may carry with it a threat to the genetic balance in an even larger area. Additionally, it must be noted that, even if the initial French tests of low-yield nuclear devices do not cause significant or notorious damage to the living organisms in Polynesia, the line between reasonableness and unreasonableness in this regard may be passed when the French decide to explode hydrogen bombs in 1967 or 1968. Thus, even if the United States' nuclear tests can be said to constitute a "precedent" for nuclear tests in general, the very notion of precedents may be unreasonable in a situation where the cumulative effect of nuclear tests (and an acceleration in magnitude within a particular "test series") may be of a different qualitative order of tolerability compared to the effect of the prior tests that are cited as a legal precedent. And, in turn, this factor must be balanced against the competing interests of other nations in the traditional uses of the high seas in the test-site area.

Moreover, a reasoned consideration of the probable effects of the French tests in the South Pacific cannot stop with those tests alone. One must also take into consideration the argument that, if the French tests are regarded as legal despite due account being taken of all the preceding factors, then it may be difficult, if not totally unreasonable, to draw a line after the French tests prohibiting new tests by other countries in the Pacific Ocean. For the United States' tests could be thought of in terms of a bipolar balance of power, or "balance of terror," whereas the French tests, as we have seen, are difficult to justify in terms of international security. Or, to put the matter differently, bipolarity is obviously a [pg76] numerically limited concept, but multipolarity — or simply nuclear proliferation_cannot justifiably be cut off at the fifth, eleventh, seventeenth, or twenty-second Power. The relevance of this consideration to the argument of the international uses of the high seas is clear. If every nation had the right to test its own nuclear arsenal in the Pacific Ocean, would there be any "regime of the high seas" left for peaceful uses? Would it not be obvious that the natural balance of oceanic life would sooner or later be upset? Would not the risk increase almost to a certainty that innocent persons outside or non-culpably inside the various warning zones would be injured or killed by the direct blast effects? Indeed, the "traditional" uses of the seas might be extinguished, not balanced. 
A third category of interests includes those of nations which might be directly affected by fallout from the French tests. Nuclear fallout could carry eastward toward South America or southwestward toward Australasia by the winds which circulate the high-pressure region of the Tuamotu island group. Contaminated water may be carried by ocean currents toward New Zealand or Australia on a south-southwest swing, or eastward toward the coast of South America to be picked up by the Humboldt Current which runs upward along the South American coast. Additionally, the entire continental and oceanic Southern Hemisphere will receive an equitable distribution of stratospheric fallout. Again, with respect to all these factors, no theoretical dividing line exists between danger and acceptable tolerance upon which all can agree. Yet the French tests will add to other radiation in the area from previous nuclear tests and perhaps exceed the tolerance level for human safety and the safety of food consumed in the countries mentioned. Diplomatic protests concerning the French tests from countries such as Australia, New Zealand, Chile and Peru attest in part to the reality of these dangers.

Finally, the category of general international law may be cited, since international law is itself the manifestation of rules of reasonable accommodation among nations, and thus expresses the general interest of all states. Two general rules are immediately relevant. First, under the Genocide Convention ratified by France on October 14, 1950, France has a duty to any ethnic group within the actual or claimed jurisdiction of France to desist from any act "committed with intent to destroy ... in part ... [an] ethnic ... group ... [by] causing serious bodily or mental harm to members of the group." FN26As reported by the official United Nations Scientific Committee on the Effects of Atomic Radiation, atmospheric nuclear tests may very well have the effect of causing serious bodily or mental harm to nearby population groups. FN27 An argument might be advanced that, in light of this possibility, any atmospheric nuclear weapons test which could have these effects on an ethnic group such as the Polynesians would be illegal under international conventional law. Second, the Moscow Test Ban Treaty of 1963FN28 may itself have started, or at least [pg77] acknowledged, a general rule of customary international law dating approximately from 1963 to the effect that all atmospheric tests of nuclear weapons are illegal. The nearly universal acceptance of the treaty indicates an international consensus of overwhelming force in favor of the principles contained therein. Any claim to the contrary must be a claim of special interest against community interest. Additionally, the treaty and subsequent practice under it (i.e., restraint from conducting atmospheric tests and restraint from withdrawing from the treaty under its withdrawal clause) can be argued to be the equivalent of the practice and acquiescence of states to a rule banning atmospheric nuclear tests even in the absence of a treaty. FN29 As in any area in which a customary principle is claimed, the basic importance of the Test-Ban Treaty here is the overwhelming (not necessarily universal) expectation of the peoples of the world about the unlawfulness of atmospheric nuclear testing.

It is evident, in conclusion, that a large number of interests and legitimate claims must be assessed, if one is to attempt to come to a determination as to the legality or illegality of the French nuclear test series either as a whole or in the hydrogen-bomb test stage now expected for 1967 or 1968. It is hoped that this paper may at least have demonstrated that the competing interests involved are substantially different from those which have been articulated in 
connection with previous atmospheric nuclear tests, and that to rely therefore on a superficial precedential similarity would be unjustified.

\section{FOOTNOTES}

*Instructor in Political Science, Wellesley College.

**Numbers in the format "pg66” etc. refer to the pagination of the original article.

FN1 Jacobs, "Tahiti Learns About the Bomb," 46 N. Y. Times Magazine 172 (Dec. 5, 1965).

FN2 Ibid.

FN3 Christian Science Monitor, Dec. 1, 1964, p. 13, col. 5.

FN4 See Capet, "Death for Tahiti," 212 Atlantic Monthly 73 (July, 1963).

FN5 McDougal and Schlei, "The Hydrogen Bomb Tests in Perspective: Lawful Measures for Security," in McDougal and Associates, Studies in World Public Order 763 (1960).

FN6 See Fliess, "The Legality of Atmospheric Nuclear Tests-A Critical View of International Law in the Cold War," 15 U. Florida Law Rev. 21 (1962).

FN7 Treaty Banning Nuclear Weapons Tests in the Atmosphere, in Outer Space and Under Water, Aug. 5, 1963, [1963] U. S. Treaties 1313; T.I.A.S., No. 5433 (effective Oct. 10, 1963); 57 A.J.I.L. 1026 (1963).

FN8 U.N. General Assembly Res. 1762 A (XVII).

FN9 See, e.g., New York Times, April 21, 1966, p. 1, col. 6.

FN10 E.g., Gallois, The Balance of Terror (1961); see also Aron, The Great Debate (1965).

FN11 The foregoing considerations do not rely on "state of the art" factors which, from a military and technological point of view, are even more compelling. For example, super-Power anti-missile (ABM) defense technology has at least a ten-year lead time over France's and the gap is widening. As between the United States and the Soviet Union, ABM systems would probably not be interpreted by decision-makers as sufficiently effective or reliable, due to concurrent anti-anti-missile technology and the advancing art of decoys. But as between a super-Power and a minor nuclear Power such as France, the super-Power's ABM system would constitute such an effective defense that the minor nuclear Power's nuclear capability would never even rise to the status of a limited credible deterrent.

FN12 See 1 Oppenheim, International Law 119-123 (Lauterpacht, $8^{\text {th }}$ ed.) 
FN13 Reflected in General Assembly Res. 1514 (XV) on the Granting of Independence to Colonial Countries and Peoples.

FN14 Journal Officiel de la République Française 9177-9179 (Oct. 5, 1958).

FN15 Omitting Guinea.

FN16 United Nations Non-Self-Governing Territories, Summaries of Information Transmitted to the Secretary-General During 1946 (1947).

FN17 U.N. General Assembly Res. 66 (I).

FN18 See General Assembly Res. 742 (VIII).

FN19 See Hydeman and Berman, International Control of Nuclear Maritime Activities 17-24 (1960).

FN20 Report of the United Nations Visiting Mission to Trust Territories in the Pacific 1956, U.N. Trusteeship Council, Official Records, 18th Sess., Supp. No. 3 (T/1278), at 45, 26-28. The scientific controversy concerning the measurable damage of nuclear weapons tests in the atmosphere is at present unresolved. The statements in the text were designed to represent a minimal consensus as to the dangers of these tests.

FN21 McDougal and Schlei, note 5 above, at 824-841.

FN22 See Margolis, "The Hydrogen Bomb Experiments and International Law," 64 Yale Law J. 629 (1955); Reiff, The United States and the Treaty Law of the Sea (1959); Taubenfeld, "Nuclear Testing and International Law," 16 Southwestern Law J. 365 (1963).

FN23 See Taubenfeld, note 22 above, at 401-402; Trail Smelter Case, 3 Int. Arb. Awards 1905; 33 A.J.I.L. 182 (1939).

FN24 See Fliess, note 6 above.

FN25 See Schwarzenberger, The Legality of Nuclear Weapons 48 (1958).

FN26 78 U. N. Treaty Series 278 (No. 1021).

FN27 For the various committee reports, see U.N. General Assembly, Official Records, Docs. Nos. A/3838, A/5216, and A/5814.

FN28 Cited note 7 above.

FN29 See D'Amato, "Treaties as a Source of General Rules of International Law," 3 Harvard Int. Law Club Journal 1 (1962). Some or all of these reasons may have been behind the comment by the United States Department of State that the explosion of Communist China's second nuclear 
device was "in total disregard of the test-ban treaty," a comment made despite the fact that China was not a party to the Test-Ban Treaty. New York Times, May 15, 1965, p. 1, col. 7; p. 2, col. 4. 